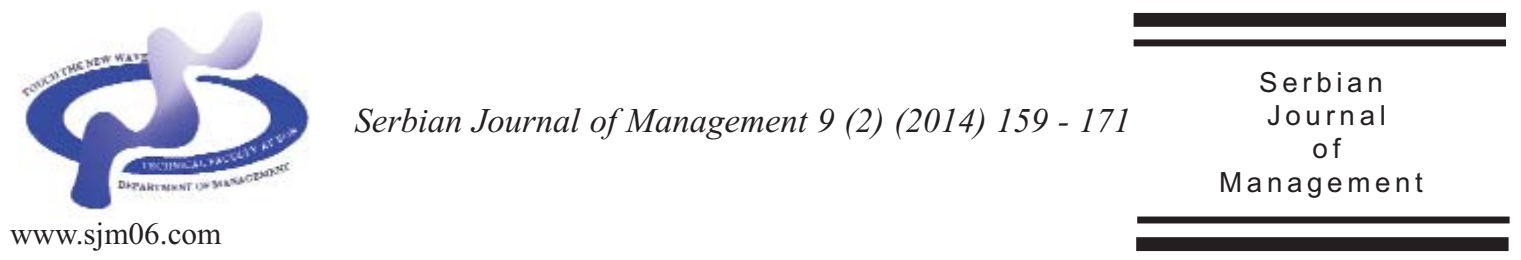

\title{
WORKSPACE AS A FACTOR OF JOB SATISFACTION IN THE BANKING AND ICT INDUSTRIES IN MACEDONIA
}

\author{
Ana Tomovska-Misoska*, Miodraga Stefanovska-Petkovska, Misko Ralev and \\ Venera Krliu-Handjiski
}
University American College Skopje, Treta Makedonska Brigada 60, 1000 Skopje, Republic of Macedonia

(Received 29 May 2014; accepted 27 June 2014)

\begin{abstract}
Job satisfaction has always been an interesting topic among the business community. One important aspect that gains more and more prominence is the relationship between physical aspects of the workspace and experienced level of job satisfaction. Although there is numerous research exploiting the link between workspace and job satisfaction in European and worldwide companies there is a lack of such research in the Republic of Macedonia and the Balkan region. Therefore the objective of this study is to investigate the relation between physical workspace environment, workspace satisfaction and employees' job satisfaction in the banking and ICT sector in the Republic of Macedonia. The study is quantitative using a questionnaire as a main research instrument implemented among 250 employees. The analysis is concentrated on uncovering the impact of various aspects of the workspace design and personalization of the workspace on workplace satisfaction and through that on job satisfaction. The results confirm that workspace satisfaction and job satisfaction depend on various elements of workspace design. Therefore significant attention should be paid to employees' perception of the workspace and the design of various aspects of the workspaces.
\end{abstract}

Keywords: workspace satisfaction, job satisfaction, workspace design, IT industry, banking industry, Republic of Macedonia

\section{INTRODUCTION}

Job satisfaction has been a topic of numerous research efforts. Some researchers consider it the most studied work related attitude in the organizational behaviour and human resource literature (Ghazzawi, 2010). Job satisfaction as a topic is quite important as it is related to organizational profitability and competitiveness (Abdullah \& Ramay, 2012). Although people spend much of their working hours in their workstation, which

\footnotetext{
*Corresponding author: tomovska@uacs.edu.mk
}

DOI:10.5937/sjm9-6347 
raises the possibility that the physical conditions they are exposed to, will influence their overall level of job satisfaction, very few efforts have been dedicated to understanding the relationship between the physical office environment, satisfaction with the workspace and the overall job satisfaction (Danielsson, 2005).

A smaller group of studies from this field, have been dedicated in uncovering the relationship that working environment has on employee job satisfaction (Diala \& Nemani, 2011; Miles et al., 2011; Frontczak et al., 2012; Pereira Da Silva et al., 2012; Öztürk et al., 2012; Rose et.al., 2013). One of the underlying motivators for such research is that insufficient knowledge of how the working environment impacts company performance and employee satisfaction leads to a poor basis for managerial decision making (Sell \& Cleal, 2011; Rose et.al, 2013). This paper seeks to contribute to the existing scientific knowledge by investigating the relation between physical workspace environment, workspace satisfaction and employees' job satisfaction in the banking and ICT sector in the Republic of Macedonia by uncovering the impact of various design elements of the workspace on workplace satisfaction and through that on job satisfaction.

\section{RESEARCHING THE NEXUS OF JOB SATISFACTION, WORKSPACE ELEMENTS AND WORKSPACE SATISFACTION}

The research of the level and determinants of job satisfaction have captured the attention of business and academic researchers alike. Special attention has been dedicated to analyzing the demographic differences in self-reported job satisfaction. For example, many studies done across different industries have found that female workers tend to experience higher levels of job satisfaction in comparison to male workers (Oshagbemi, 2000; Bender et al., 2005). Another stream of academic research finds that men are more satisfied than women on their jobs (Crossman \& AbouZaki, 2003; Okpara, 2006). This research will investigate the difference in the job satisfaction levels between employees with different genders. Accordingly research hypothesis 1, resulting from above theoretical approaches is: There is a difference in the job satisfaction between employees with different genders.

Research has also found that job satisfaction increases with age and tenure in the organization. Older employees and employees who have spent more time in the organization, tend to experience higher levels of job satisfaction compared to younger employees and employees who were new to the organization (Lee \& Wilbur, 1985; Bedeian et al., 1992). This is attributed to the fewer alternative employment options, lower expectations and better identification with the organizational culture of older employees and employees with longer tenure in the organization. Therefore this research will investigate the difference in the job satisfaction between employees with different years of experience of working within the company. Accordingly research hypothesis 2, resulting from above theoretical approaches is: There is a difference in the job satisfaction between employees with different years of experience of working within the company.

Other research has been dedicated to uncovering personal traits, the work itself, relationship with colleagues and supervisors, 
feelings of job security, self accomplishmenet and fulfillment, satisfaction with salary, opportunity of promotion and adavancement and similar variables (Robbins \& Judge, 2009).

Although job satisfaction has long been the focus of attentions to researchers from organizational science, the relationship between workspace design and job satisfaction is less prevalent in the literature. The physical work environment, such as the office space and workstation design, is provided by management to the employee, thus can be considered as an expression of management's attitudes towards the employee. The review of the literature reveals that people who live in industrialized countries spend approximately $90 \%$ of their time doing indoor work. Besides its impact to the job satisfaction the nature of the work is important factor that influences the office design too so that the assumption is: better workplace environment produces better job results and increased productivity (Hameed \& Amjad, 2009). Newsham et al. (2009) consider this as a two way relationship - that the satisfaction of employees with their workspace would contribute to the higher satisfaction with the job as another aspect of the employment relationship.

One of the earliest studies investigating this relationship was done in the field of environmental psychology by Sundstrom (1986) and examined the effect of workspace design (with special focus on offices) on individuals. Certain authors have connected the elements of the workspace with employees' health through assessment of symptoms of the sick building syndrome (headache, fatigue, stuffy nose, weakened eyesight etc.) (Aaras et al., 2001; Brasche et al., 2001; Chao et al., 2003; Stenberg et al., 1994).
Wineman \& Adhya (2007) examined the relationship between psychosocial measures and a set of objective measures of the spatial layout of the office. The results of the study show that high levels of job satisfaction are associated with positive perceptions of other aspects of workplace like privacy, interaction support, sense of community and autonomy. On the other hand Brill et al. (2001) found that the physical workplace environment contributes for $24 \%$ of job satisfaction rates. In line with these findings, other research has also found that physical elements of the workplace contribute to the reported level of job satisfaction. According to research done by Frontczak et al. (2012) satisfaction with amount of space was ranked to be most important for workspace satisfaction, regardless of age group (below 30, 31-50 or over 50 years old), gender, type of office (single or shared offices, or cubicles), distance of workspace from a window (within $4.6 \mathrm{~m}$ or further), or satisfaction level with workspace (satisfied or dissatisfied).

In addition, numerous studies have found connections between different aspects of the workspace, workspace satisfaction and overall job satisfaction. As a result of the studies it has been found that employees in cell-offices (single-person office) are the most satisfied with design-related factors and the employees in flex-offices (without work station) were most satisfied with the social aspects of their physical environment. Employees in shared (2-4 people sharing a room) and combi-offices (without strict spatial definition) were most dissatisfied on the matter of noise and privacy and employees in open plan offices (10-20 person rooms) report highest dissatisfaction on all matters (Danielsson, 2005). This study will investigate whether employees in single offices will be more satisfied with the 
workspace and privacy levels. Accordingly research hypothesis 3, resulting from above theoretical approaches is: Employees in single offices will be most satisfied with the workspace and privacy levels.

A study conducted by Newsham et al. (2009), uncovers that satisfaction with the workspace environment is linked to the overall job satisfaction with that relationship moderated by satisfaction with management and compensation. The study also found connections between satisfaction with lighting, ventilation, privacy and acoustics, design of the workspace and overall environmental satisfaction. As far as lighting is concerned the study pointed that having a window and good natural light is very important for the workers satisfaction. Similar findings regarding privacy/acoustics, satisfaction with lighting and ventilation/temperature were found in other studies as well (Veitch et al., 2003; Veitch et al., 2007). Other studies have been mostly concerned with the amount of privacy, distractions and personalization of the workspace as well as the possibilities to experience psychosocial support through the design of the workspaces. For example, Wineman \& Adhya (2007) examined the connections between experienced privacy, support during interactions, sense of community and autonomy as psychosocial aspects that the workspace can fulfil as well as spatial layout of the workspace and the job satisfaction. Connectivity as part of the workspace design was connected to perceived interaction support and local integration was connected to perceived sense of community and through those psychosocial elements the physical workspace elements were connected to the job satisfaction. Similar findings regarding support for interactions were also found by
Wolfeld (2010) who pointed that the frequency of interactions that the employees expressed to have with other employees were positively correlated with the job satisfaction. When it comes to amount of personalization that the workspace offers a number of studies have found that the amount of control that the workers have in their workspace (Knight \& Haslam, 2010), the flexibility that the workers have in making changes to the workspace to accommodate for personal needs (Lee \& Brand, 2005) as well as the possibilities for personalization of the workspace were connected to the workspace satisfaction and the overall job satisfaction (Miles \& Perewe, 2011). This study will look whether higher experienced freedom from distraction, satisfaction with the meeting spaces, storage space, lighting, privacy, air quality and temperature will be connected to higher workspace satisfaction. Accordingly research hypothesis 4 is: The higher experienced freedom from distraction, satisfaction with the meeting spaces, storage space, lighting, privacy, air quality, temperature and personalization will be connected to higher workspace satisfaction.

In addition we will look whether higher experienced freedom from distraction, satisfaction with the meeting spaces, storage space, lighting, privacy, air quality, temperature and overall workspace satisfaction will be connected to higher job satisfaction. Resulting research hypothesis, research hypothesis 5 is accordingly: The higher experienced freedom from distraction, satisfaction with the meeting spaces, storage space, lighting, privacy, air quality, temperature, personalization and workspace satisfaction will be connected to higher job satisfaction. 


\section{METHODOLOGY}

To help understand the various aspects of workspace satisfaction among workers in the ICT and banking industries in the Republic of Macedonia this study used a questionnaire. Some questions were based on previous studies to enable comparison of the results. As such some questions were adapted to the Macedonian context from the studies done by Danielsson (2005), Newsham et al. (2009) and Veitch et al. (2007) and other questions were specifically constructed for this study. The questions used in the analysis are given in Appendix 1.

The study was done from January to March 2014 in two companies from the ICT sector and three banks in the Republic of Macedonia. The study used convenient sampling. Although this type of sampling is non-representative and the generalizability of the findings might be compromised it can be used in exploratory studies and as a base for further research (Coolican, 2004). Having in mind that this study is first of its kind in the country and is mainly aiming at gaining an exploratory insight into the situation, this type of sampling was deemed appropriate.
The sample consisted of 250 employees from two different companies. Out of the total number of employees 55, $1 \%$ were female and 44, 9\% were male. Most of the participants were in the age group 26-35 (51,4\% of the respondents) followed by $36-$ 45 year old (29,6\% of the respondents), 4655 year old $(9,5 \%)$ and $18-25(5,8 \%)$ as shown in Table 1. Most of the participants did not supervise other people $(68,6 \%)$. Furthermore most of the participants have been working for the company between 1 and 5 years as it can be seen in Table 1 .

To test the research hypotheses several variables were constructed for the purpose of the study: defocus - consisted of seven items that measure the exposition to noise and visual distraction that defocus the employee from his/her work; meeting - consisted of two items which assessed the satisfaction with the formal and informal meetings in the building; storagespace - consisted of two items that measured satisfaction with the location and usability of the storage space; lighting - consisted of three items that measured satisfaction with natural, artificial and overall lighting; privacy - consisted of two items which measured the amount of visual and conversation privacy; temperature - consisted of one item measuring the

Table 1. Distribution of respondents in regards to age group and work experience within the company

\begin{tabular}{lccc}
\hline & \multicolumn{3}{c}{ Rotated factor weigh } \\
\cline { 2 - 4 } & $\begin{array}{c}\text { In case of questions } \\
\text { on BB Generation } \\
\text { members }\end{array}$ & $\begin{array}{c}\text { In case of } \\
\text { questions on } \\
\text { Generation X } \\
\text { members }\end{array}$ & $\begin{array}{c}\text { In case of questions on } \\
\text { Generation Y members }\end{array}$ \\
\hline Personal interest & 0.895 & 0.865 & 0.896 \\
Interest of the other side & 0.835 & 0.865 & 0.886 \\
Practical knowledge & 0.917 & 0.906 & 0.877 \\
Theoretical knowledge & 0.909 & 0.873 & 0.673 \\
\hline
\end{tabular}


satisfaction with the temperature in the space; window view- measuring the satisfaction with the office view; workspace satisfaction - consisted of five items measuring the overall satisfaction with the workspace; and job satisfaction - consisted of two items measuring the overall job satisfaction. The factor analysis done for the dependant (Table 2) and independent variables (Table 3 ) confirmed the grouping of the variables.

After the factor analysis, reliability test was performed. All the scales used in the analysis showed Cronbach Alpha values higher than 0,7 which makes them acceptable for further usage.

Table 2. Dependent variables factor analysis

\begin{tabular}{|c|c|c|}
\hline \multirow[b]{2}{*}{ Rotated Component Matrix ${ }^{a}$} & \multicolumn{2}{|c|}{ Component } \\
\hline & $\begin{array}{c}\text { Factor } 1 \\
\text { Workspace } \\
\text { satisfaction }\end{array}$ & $\begin{array}{c}\text { Factor } 2 \\
\text { Job } \\
\text { satisfaction }\end{array}$ \\
\hline Job satisfaction & .366 & .783 \\
\hline Recoded Q520 (Disappointment with job) & .090 & .915 \\
\hline Workspace attractive aspect of job & .770 & .103 \\
\hline Very satisfied with my workspace & .880 & .207 \\
\hline Positive working atmosphere & .799 & .209 \\
\hline User friendly space & .800 & .199 \\
\hline Well thought-out & .806 & .265 \\
\hline
\end{tabular}

Extraction Method: Principal Component Analysis.

Rotation Method: Varimax with Kaiser Normalization.

a. Rotation converged in 3 iterations.

Table 3. Independent variables factor analysis

\begin{tabular}{|c|c|c|c|c|c|}
\hline \multirow[b]{2}{*}{$\begin{array}{c}\text { Rotated } \\
\text { Component Matrix }^{\mathrm{a}}\end{array}$} & \multicolumn{5}{|c|}{ Component } \\
\hline & $\begin{array}{l}\text { Factor } 1 \\
\text { Defocus }\end{array}$ & $\begin{array}{l}\text { Factor } 2 \\
\text { Lighting }\end{array}$ & $\begin{array}{c}\text { Factor } 3 \\
\text { Storage } \\
\text { space }\end{array}$ & $\begin{array}{l}\text { Factor } 4 \\
\text { Privacy }\end{array}$ & $\begin{array}{c}\text { Factor } 5 \\
\text { Meeting } \\
\text { space }\end{array}$ \\
\hline Defocus activities & .770 & .029 & .067 & -.186 & -.073 \\
\hline Defocus talks & .826 & -.029 & -.049 & -.188 & .041 \\
\hline Defocus computer & .776 & -.154 & -.065 & .015 & -.041 \\
\hline Defocus phone & .751 & -.034 & -.120 & .082 & -.059 \\
\hline Defocus outside noise & .775 & -.089 & -.005 & .087 & -.048 \\
\hline Too much activity & .770 & -.084 & -.180 & -.163 & -.032 \\
\hline Formal meeting space & -.064 & .042 & .238 & .250 & .772 \\
\hline Informal meeting space & .007 & .018 & .217 & .182 & .800 \\
\hline Informal talks & .755 & -.102 & -.030 & -.155 & .051 \\
\hline Storage space & -.129 & .164 & .895 & .186 & .115 \\
\hline Location of storage space & -.100 & .182 & .910 & .110 & .097 \\
\hline Natural lighting & -.088 & .859 & .050 & .100 & .080 \\
\hline Artificial lighting & -.078 & .854 & .196 & .136 & .102 \\
\hline Overall lighting & -.146 & .933 & .119 & .080 & .057 \\
\hline Conversation privacy & -.193 & .161 & .151 & .860 & .132 \\
\hline Visual privacy & -.092 & .147 & .146 & .903 & .094 \\
\hline
\end{tabular}




\section{RESULTS}

To test the Hypothesis 1 a Mann-Whitney test was performed since the assumption for homogeneity of variance was not fulfilled (Levene's test significant) to perform a t-test. The test showed no significant difference between the genders when it comes to job satisfaction $(p=0.927 ; p>0.05)$. This result is different from other findings, which found significant differences in levels of job satisfaction experience by men and women (Crossman \& Abou-Zaki, 2003; Ghazzawi, 2010; Okpara, 2006; Oshagbemi, 2000).

Hypothesis 2 was tested by ANOVA. The test revealed statistically significant difference between workers with different work experience $(p=0.04 ; p<0.05)$. The highest level of job satisfaction was experienced by workers working in the company less than a year and the lowest level was experienced by workers working in the company between 16 and 20 years.

To test the Hypothesis 3, ANOVA was performed with the office type as grouping variable the variables workspace satisfaction and privacy. As it can be seen from Table 4 the Hypothesis was partially supported as there was statistically significant difference only in the satisfaction with privacy between employees in different office types. The post-hoc analysis revealed that there is statistically significant difference between the workers in individual office $(M=3,67)$ and workers in the other two types of offices: sharing with colleagues $(M=3,05)$ and open office $(M=2,66)$. There was also statistical significance in the level of satisfaction with privacy between employees working in office shared with colleagues and open office. This result is similar to the findings of other studies as well (Danielsson, 2005).

The testing of the Hypothesis 4 was performed using regression analysis. The analysis showed that $54 \%$ of the variance in the dependent variable workspace satisfaction was explained by the independent variables and the overall model can statistically significant predict the outcome variable $(F=39,611 ; p<0.01)$. The results in Table 5 show that satisfaction with storage space $(\beta=0.214, p<0.01)$, satisfaction with lighting $(\beta=0.212, p<0.01)$, satisfaction with privacy $(\beta=0.260, \quad \mathrm{p}<0.01)$ and satisfaction with air quality $(\beta=0.124$, $\mathrm{p}<0.05)$ significantly predict workspace satisfaction. Although satisfaction with meeting space, freedom from distraction and temperature were found to be nonsignificant, the findings are in line with findings from different studies (Knight \& Haslam, 2010; Veitchet.al., 2003; Veitchet.al., 2007).

Table 4. ANOVA of satisfaction with workspace and privacy by type of office

\begin{tabular}{|c|c|c|c|c|c|c|}
\hline & & Sum of Squares & $\mathrm{df}$ & Mean Square & $\mathrm{F}$ & Sig. \\
\hline \multirow{3}{*}{ Privacy } & $\begin{array}{c}\text { Between } \\
\text { Groups }\end{array}$ & 23.981 & 2 & 11.990 & 11.854 & .000 \\
\hline & Within Groups & 246.797 & 244 & \multirow[t]{2}{*}{1.011} & \multirow{5}{*}{.046} & \multirow{5}{*}{.955} \\
\hline & Total & 270.777 & 246 & & & \\
\hline \multirow{3}{*}{$\begin{array}{l}\text { Workspace } \\
\text { satisfaction }\end{array}$} & $\begin{array}{l}\text { Between } \\
\text { Groups }\end{array}$ & .050 & 2 & .025 & & \\
\hline & Within Groups & 130.619 & 243 & \multirow[t]{2}{*}{.538} & & \\
\hline & Total & 130.669 & 245 & & & \\
\hline
\end{tabular}


Table 5. Regression analysis of Research hypothesis 4

\begin{tabular}{llccccc}
\hline \multirow{2}{*}{ Model } & \multicolumn{2}{c}{ Unstandardized Coefficients } & \multicolumn{2}{c}{$\begin{array}{c}\text { Standardized } \\
\text { Coefficients }\end{array}$} & $\mathrm{t}$ & Sig. \\
\cline { 2 - 4 } & \multicolumn{2}{c}{$\mathrm{B}$} & Std. Error & Beta & & \\
\hline \multirow{2}{*}{ (Constant) } & 1.167 & .228 & & 5.129 & .000 \\
& Defocus & -.059 & .041 & -.068 & -1.450 & .148 \\
& Meeting & .058 & .033 & .085 & 1.754 & .081 \\
\multirow{4}{*}{1} & Storagespace & .145 & .035 & .214 & 4.151 & .000 \\
& Lighting & .180 & .045 & .212 & 4.036 & .000 \\
& Privacy & .180 & .038 & .260 & 4.759 & .000 \\
& Temperature & .090 & .048 & .115 & 1.866 & .063 \\
& Air quality & .083 & .040 & .124 & 2.066 & .040 \\
\hline
\end{tabular}

a. Dependent Variable: Workspace satisfaction

Finally, Hypothesis 5 was tested using regression analysis. The analysis showed that $31 \%$ of the variance in the dependent variable job satisfaction was explained by the independent variables. Although the model explains small portion of the overall varianceit can still statistically significant predict the outcome variable $(\mathrm{F}=12,982$; $\mathrm{p}<0.01)$. As it can be seen in Table 6, freedom from distraction $(\beta=-0.255, p<0.01)$ satisfaction with meeting space $(\beta=0.154$, $\mathrm{p}<0.05)$, and overall workspace satisfaction $(\beta=0.321, \quad p<0.01) \quad$ significantly predict workspace satisfaction.

\section{CONCLUSION}

The aim of this study was to analyse how workspace design determines the level of job satisfaction among 250 employees in the Macedonian banking and ICT industry. The test showed no significant difference between the genders when it comes to job satisfaction, which was contrary to dominant studies from the field. In relation to workyears spent at the company, the highest level of job satisfaction was experienced by workers working in the company less than a year and the lowest level was experienced by workers working in the company between 16 and 20 years.A statistically significant difference was found in the satisfaction with privacy between employees in different office types and in the level of satisfaction with privacy between employees working in office shared with colleagues and open office. This result is similar to the findings of other studies as well (Danielsson, 2005). In Table 6. Regression analysis of Research hypothesis 5

Coefficients $^{\mathrm{a}}$

\begin{tabular}{|c|c|c|c|c|c|c|}
\hline & \multirow[t]{2}{*}{ Model } & \multicolumn{2}{|c|}{ Unstandardized Coefficients } & \multirow{2}{*}{$\begin{array}{c}\begin{array}{c}\text { Standardized } \\
\text { Coefficients }\end{array} \\
\text { Beta } \\
\end{array}$} & \multirow[t]{2}{*}{$\mathrm{t}$} & \multirow[t]{2}{*}{ Sig. } \\
\hline & & $\mathrm{B}$ & Std. Error & & & \\
\hline \multirow{9}{*}{1} & (Constant) & 2.898 & .336 & & 8.622 & .000 \\
\hline & Defocus & -.254 & .058 & -.255 & -4.415 & .000 \\
\hline & Meeting & .121 & .047 & .154 & 2.559 & .011 \\
\hline & Storagespace & -.020 & .051 & -.027 & -.404 & .687 \\
\hline & Lighting & .044 & .065 & .046 & .687 & .493 \\
\hline & Privacy & .004 & .055 & .005 & .067 & .946 \\
\hline & Temperature & -.059 & .068 & -.067 & -.869 & .386 \\
\hline & Air quality & .061 & .057 & .079 & 1.063 & .289 \\
\hline & Workspace satisfaction & .365 & .091 & .321 & 4.011 & .000 \\
\hline
\end{tabular}

a. Dependent Variable: JS 
addition the analysis of the results showed that satisfaction with storage space, satisfaction with lighting, satisfaction with privacy and satisfaction with air quality significantly predict workspace satisfaction. These findings were in line with other studies done across different industries in Europe. In addition, workspace satisfaction, satisfaction with the meeting space and freedom from distraction significantly predict the overall job satisfaction. The findings points to the importance of the design elements of the workspace for job satisfaction. The important element in the link is the perception of employees of various physical aspects of the workspace as well as their experiences of working in such environment.
Although this is a first study of its kind done in the Republic of Macedonia and it uses convenient sampling it still implies very important lessons for the companies. Namely, the management of the companies should pay close attention to the design elements of the workspace and employees' perception of those elements as they are important for the workspace satisfaction and overall job satisfaction. This can be done through consultations with the employees and closely monitoring their experience to help design workspaces that will be conducive for reaching higher levels of job satisfaction. Future research should also help in further understanding the elements of the workspace that create the highest level of job satisfaction.

\title{
РАДНИ ПРОСТОР КАО ФАКТОР ЗАДОВОЉСТВА ПОСЛОМ У БАНКАРСКОМ СЕКТОРУ И ИКТ ИНДУСТРИЈИ У МАКЕДОНИЈИ
}

\author{
Ana Tomovska-Misoska*, Miodraga Stefanovska-Petkovska, Misko Ralev and \\ Venera Krliu-Handjiski
}

\section{Извод}

Задовољство послом одувек представља интересантан сегмент у пословном окружењу. Важан аспект, који добија све више на значају, је зависност између физичких атрибута радног простора и исказаног нивао задовољства послом. Иако постоји велику број истраживања која истражују ову везу, у Европским и светским компанијама, постоји недостатак такве врсте истраживања у Македонији и уопште на Балкану. Према томе циљ овог истраживања је да истражи однос између физичког окружења радног простора, задовољства радним простором и задовољства радним местом запосленог у банкарском сектору и сектору ИКТ у Македонији. Студија је квантитативне природе уз употребу упитника као главног истраживачког инструмента на узорку од 250 запослених. Анализа је фокусирана на откривање утицаја различитих аспеката дизајна радног места и персонализације радног простора на укупоно задовољство запослених. Резултати потврђују да је задовољство радним местом и радним простором зависно од различитих елемената дизајна радног простора. Због тога, значајна пажња мора се усмерити ка перцепцији запослених о радном простору и дизајну различитих елемената истог.

Кључне речи: задовољство радним местом, задовољство послом, дизајн радног простора, ИКТ индустрија, банкарски сектор, Република Македонија 


\section{References}

Aaras, A., Horgen, G., Bjorset, H.H., Ro, O., \& Walsoe, H. (2001). Musculoskeletal, visual and psychosocial stress in VDU operators before and after multidisciplinary ergonomic interventions: A 6 years prospective study - Part II. Applied Ergonomics, 32 (6), 559-571.

Abdullah, \& Ramay, M.I. (2012). Antecedents of organizational commitment of banking sector employees in Pakistan. Serbian Journal of Management, 7 (1), 89-102.

Bedeian, A.G., Ferris, G.R. \& Kacmar, K.M. (1992). Age, tenure, and job satisfaction: A tale of two perspectives. Journal of Vocational behavior, 40 (1), 33-48.

Bender, K.A., Donohue, S.M., \& Heywood, J.S. (2005). Job satisfaction and gender segregation. Oxford economic papers, 57 (3), 479-496.

Brasche, S., Bullinger, M., Morfeld, M., Gebhardt, H.J., \& Bischof, W. (2001). Why do women suffer from sick building syndrome more often than men? - subjective higher sensitivity versus objective causes. Indoor Air, 11, 217-222.

Brill, M., Weidemann, S. and BOSTI Associates (2001). Disproving Widespread Myths About Workplace Design. Jasper, IN, USA: Kimball International.

Chao, H.J., Schwartz, J., Milton, D.K., \& Burge, H.A. (2003). The work environment and workers' health in four large office buildings. Environmental Health Perspectives, 111 (9), 1242-1248.

Coolican, H. (2004). Research methods and statistics in psychology. Abingdon: Hodder Arnold.

Crossman, A., \& Abou-Zaki, B. (2003). Job satisfaction and employee performance of Lebanese banking staff. Journal of Managerial Psychology, 18 (4), 368-376.

Danielsson, C. (2005). Office Environment, Health \& Job Satisfaction. Stockholm Tryck: Universitets service US $\mathrm{AB}$.

Diala, I., \& Nemani, R. (2011). Job Satisfaction: Key Factors Influencing Information Technology (IT) Professionals in Washington DC. International Journal of Computer Technology and Applications, 2 (4), 829-830.

Frontczak, M., Schiavon, S., Goins, J., Arens, E., Zhang, H., \& Wargocki, P. (2012). Quantitative relationships between occupant satisfaction and satisfaction aspects of indoor environmental quality and building design. Indoor Air, 22, 119-131.

Ghazzawi, I. (2010). Gender Role in Job Satisfaction: The Case of the U.S. Information Technology Professionals. Journal of Organizational Culture, Communications and Conflict, 14 (2), 1-34.

Hameed, A., \& Amjad, S. (2009). Impact of Office Design on Employees' Productivity: A Case Study of Banking Organizations of Abbottabad, Pakistan. Journal of Public Affairs, Administration and Management, 3 (1), 1-13.

Knight, C., \& Haslam, A.S. (2010). Your Place or Mine? Organizationalidentification and comfort as mediators of relationshipsbetween the managerial control of workspace and employees' satisfaction and well-being. British Journal of Management, 21, 717-735.

Lee, R., \& Wilbur, E.R. (1985). Age, Education, Job Tenure, Salary, Job Characteristics, and Job Satisfaction: A multivariate analysis. Human Relations, 38 (8), 781-791.

Lee, S.Y. and Brand, J.L. (2005) Effects of control over workspace on perceptions of 
the work environment and work outcomes. Journal of Environmental Psychology, 25(3), 323-333.

Miles, A.K., \& Perrewe, P.L. (2011). The Relationship Between Person-Environment Fit, Control, and Strain: The Role of Ergonomic Work Design and Training. Journal of Applied Social Psychology, 41, 729-772.

Newsham, G., Brand, J., Donnely, C., Veitch, J., Aries, M., \& Charles, K. (2009). Linking Indoor Environment Conditions to Job Satisfaction: A Field Study. Building Research \& Information, 37 (2), 129-147.

Okpara, J.O. (2006). Gender and the Relationship Between Perceived Fairness in Pay, Promotion, and Job Satisfaction in a Sub-Saharan African Economy. Women in Management Review, 21 (3), 224-240.

Oshagbemi, T. (2000). Gender Differences in the Job Satisfaction of University Teachers. Journal of Women in Management Review, 15 (7), 331-343.

Öztürk, E., Yılmazer, S., \& Ural, S.E. (2012). The effects of achromatic and chromatic color schemes on participants' task performance in and appraisals of an office environment. Color Research \& Application, 37, 359-366.

Pereira Da Silva, M., Amaral, F.G., Mandagara, H., \& Leso, B.H. (2012). Difficulties in quantifying financial losses that could be reduced by ergonomic solutions. Human Factors and Ergonomics in Manufacturing and Service Industries, 24 (4), 415-427.

Robbins, S.P., \& Judge, T.A. (2009). Organizational Behavior. London: Pearson Educational.

Rose, L.M., Orrenius, U.E., \& Neumann, W.P. (2013). Work Environment and the Bottom Line: Survey of Tools Relating Work Environment to Business Results. Human
Factors and Ergonomics in Manufacturing and Service Industries, 23 (5), 368-381.

Sell, L., \& Cleal, B. (2011). Job Satisfaction, Work Environment, and Rewards: Motivational Theory Revisited. LABOUR, 25 (1), 1-23.

Stenberg, B., Eriksson, N., Hoog, J., Sundell, J., \& Wall, S. (1994). The sick building syndrome (SBS) in office workers: A case-referent study of personal, psychosocial and building-related risk indicators. International Journal of Epidemiology, 23 (6), 1190-1197.

Sundstrom, E. (1986). Work places: The psychology of the physical environment in offices and factories. Cambridge: Cambridge University Press.

Veitch, J.A., Charles, K.E., Farley, K.M.J., \& Newsham, G.R. (2007). A model of satisfaction with open-plan office conditions: COPE field findings. Journal of Environmental Psychology, 27 (3), 177-189.

Veitch, J.A., Charles, K.E., Newsham, G.R., Marquart, C.J.G., \& Geerts, J. (2003). Environmental Satisfaction in Open-Plan Environments: 5. Workstation and Physical Condition Effects. NRC Institute for Research in Construction. Available at: http://doi.org/10.4224/20378817 (Accessed 13.05.2014).

Wineman, J., \& Adhya, A. (2007). Enhancing Workspace Performance: predicting the influence of spatial and psychosocial factors on job satisfaction.Proceedings, 6th International Space Syntax Symposium, İstanbul, 1-15.

Wolfeld, L.R. (2010). Effects of Office Layout on Job Satisfaction, Productivity and Organizational Commitment as Transmitted through Face-to-Face Interactions. Colonial Academic Alliance Undergraduate Research Journal, 1 (8). Available at: http://scholarworks.gsu.edu/caaurj/vol1/iss 1/8 (Accessed on 13.05.2014). 


\section{APPENDIX 1.}

The questionnaire used for collecting the research data

1. How old are you?
$18-25$ b) $26-35$
c) $36-45$
d) $46-55$
e) over 55

2. Gender:

a) Male

b) Female

3. Please select which type best describes your working space?
a) Individual office
b) Shared office
c) Ocean type office
4. Do you supervise other people?
a) Yes
b) No

5. Job satisfaction questions

\begin{tabular}{|l|c|c|c|c|c|}
\hline & Strongly & Disagree & Neutral & Agree & Strongly \\
& disagree & & & & agree \\
\hline I am disappointed that I ever took this job & 1 & 2 & 3 & 4 & 5 \\
\hline I am very satisfied with my job & 1 & 2 & 3 & 4 & 5 \\
\hline
\end{tabular}

6. Workspace satisfaction questions

\begin{tabular}{|c|c|c|c|c|c|}
\hline & $\begin{array}{l}\text { Strongly } \\
\text { disagree }\end{array}$ & Disagree & Neutral & Agree & $\begin{array}{l}\text { Strongly } \\
\text { agree }\end{array}$ \\
\hline $\begin{array}{l}\text { My workspace stimulates positive working } \\
\text { atmosphere }\end{array}$ & 1 & 2 & 3 & 4 & 5 \\
\hline My workspace is user-friendly & 1 & 2 & 3 & 4 & 5 \\
\hline My workspace is a meaningful space & 1 & 2 & 3 & 4 & 5 \\
\hline $\begin{array}{l}\text { My workspace is an attractive aspect of the } \\
\text { job }\end{array}$ & 1 & 2 & 3 & 4 & 5 \\
\hline I am very satisfied with my workspace & 1 & 2 & 3 & 4 & 5 \\
\hline
\end{tabular}




\section{Satisfaction with elements of workspace}

\begin{tabular}{|l|c|c|c|c|c|}
\hline & $\begin{array}{l}\text { Strongly } \\
\text { disagree }\end{array}$ & Disagree & Neutral & Agree & $\begin{array}{l}\text { Strongly } \\
\text { agree }\end{array}$ \\
\hline $\begin{array}{l}\text { I am often distracted by activity in nearby } \\
\text { areas or people passing by when I work }\end{array}$ & 1 & 2 & 3 & 4 & 5 \\
\hline $\begin{array}{l}\text { I am often distracted by other peoples' } \\
\text { conversation }\end{array}$ & 1 & 2 & 3 & 4 & 5 \\
\hline $\begin{array}{l}\text { I am often distracted by computers or other } \\
\text { office machines }\end{array}$ & 1 & 2 & 3 & 4 & 5 \\
\hline $\begin{array}{l}\text { I am often distracted by telephone ringing } \\
\text { I am often distracted by noise from outside } \\
\text { the building }\end{array}$ & 1 & 2 & 3 & 4 & 5 \\
\hline $\begin{array}{l}\text { There is too much informal conversation } \\
\text { around me that affects my work }\end{array}$ & 1 & 2 & 3 & 4 & 5 \\
\hline $\begin{array}{l}\text { There is too much activity around my } \\
\text { workspace that affects my work }\end{array}$ & 1 & 2 & 3 & 4 & 5 \\
\hline
\end{tabular}

\begin{tabular}{|l|c|c|c|c|}
\hline & $\begin{array}{l}\text { Very } \\
\text { dissatisfied }\end{array}$ & Dissatisfied & Satisfied & $\begin{array}{l}\text { Very } \\
\text { satisfied }\end{array}$ \\
\hline Outside view of the workspace & 1 & 2 & 3 & 4 \\
\hline Usability of storage space & 1 & 2 & 3 & 4 \\
\hline Location of storage space & 1 & 2 & 3 & 4 \\
\hline Natural lighting & 1 & 2 & 3 & 4 \\
\hline Artificial lighting & 1 & 2 & 3 & 4 \\
\hline Overall lighting & 1 & 2 & 3 & 4 \\
\hline Amount of conversation privacy & 1 & 2 & 3 & 4 \\
\hline Amount of visual privacy & 1 & 2 & 3 & 4 \\
\hline Temperature & 1 & 2 & 3 & 4 \\
\hline Space for informal meetings & 1 & 2 & 3 & 4 \\
\hline Space for formal meetings & 1 & 2 & 3 & 4 \\
\hline
\end{tabular}

